\title{
Paideusis
}

\section{Reason and Values: New Essays in Philosophy of Education (John P. Portelli and Sharon Bailin (Eds.))}

\section{Douglas J. Simpson}

Volume 8, Number 1, 1994

URI: https://id.erudit.org/iderudit/1073266ar

DOI: https://doi.org/10.7202/1073266ar

See table of contents

Publisher(s)

Canadian Philosophy of Education Society

ISSN

0838-4517 (print)

1916-0348 (digital)

Explore this journal

Cite this review

Simpson, D. (1994). Review of [Reason and Values: New Essays in Philosophy of Education (John P. Portelli and Sharon Bailin (Eds.))]. Paideusis, 8(1), 45-47.

https://doi.org/10.7202/1073266ar 
And because educational bandwagons come and go, "we need to be less concerned with hearing allegiance paid to whatever happens to be the fashionable trend at the time" (p. 162) and more concerned with the personal, human qualities of the teacher. Hare's aim is not only to better serve students but to restore "meaning and dignity to the idea of teaching" (p. 162). How to assess the possession of important personal qualities in teaching candidates, and whether we can help people develop these qualities, is the subject for another book. This book is a refreshing reminder that in an age of high-tech, highperformance living, ethics and ideals are still the human bedrock upon which education must stand.

Reviewed by Deborah Court, Maimonides School, Vancouver

John P. Portell \& Sharon Bailin (Eds.), Reason and Values: New Essays in Philosophy of Education (Calgary, AB: Detselig Enterprises Limited, 1993).

This volume is, as William Hare notes in the "Introduction," a collection of essays that represents "recent work in philosophy of education in Canada" (p. 2). In particular, the essays represent the thinking of a variety of Canadian philosophers of education on topics such as "empowerment, democracy, autonomy, critical thinking, gender, the hidden curriculum, relativism, and creativity" (p. 6) that are of interest to many of their colleagues around the world.

These concepts and related concerns are discussed from a philosophical perspective that retains an appreciation for philosophical analysis while promoting an imaginative and reflective inquiry into normative issues. As the title suggests, the concepts of reason and values played a major role in the selection of the essays. Reason, viewed broadly as publicly examinable arguments, is used to explore a broad range of value questions and to suggest positions that are, at least to the authors, more meritorious than those frequently found in educational discussions today. In their essays, the authors are less than tepid as they examine contemporary topics of interest to their peers and, to a lesser degree, to intending and practising educators. The result is a set of refreshing essays that offers no protection for any position that is not carefully considered.

The volume falls neatly, if unevenly, into five sections. The first section, composed of one chapter, provides a brief overview of the subject of philosophy of education. While traditional philosophy of education is briefly treated, the majority of the chapter is devoted to analytic philosophy of education, to criticisms of the field, and to its strengths and weaknesses. In particular, Portelli distinguishes between the stereotypical descriptions of analytic philosophy of education, the claims of earlier analytic philosophers of education, and the contributions of current analytic philosophy of education. He devotes special attention to the earlier and ongoing examination of normative questions by analytic philosophers. This essay, therefore, sets the tone and direction of the remaining chapters. Writers scnutinize a number of present-day ambiguities, assumptions, dichotomies, positions, and arguments that are found in current educational discussions. On occasions, an author appears to fall into what may be termed the analytic philosopher's conceptual abyss. That is to say, every possible meaning or significance of a concept is explicated at times regardless of whether it is 
relevant to pedagogical thought or practice. As a whole, however, the discussion is germane to educators and teacher educators.

In the second section entitled "Reason and Critical Thinking," Bailin and Selman separately examine the concepts of rationality, intuition, and critical thinking. Bailin argues against dichotomizing rationality and intuition and for understanding the difference between successful and unsuccessful intuition. Likewise, she avers, "reason and emotion are not necessarily opposed one to another, but are, in fact, closely intertwined" (p. 45). Selman's discussion of critical thinking as a social practice manifests itself in an imaginary dialogue on the topic of whether or not we are neglecting important features of the concept of the critical thinker if we focus upon the teaching and testing of a specific set of measurable intellectual moves, skills, and abilities. Selman's essay may perk the interest, as well as invite the wrath, of those on both sides of the conceptualempirical debate pursued by McPeck, Ennis, and Norris.

The third division, entitled "Values: Moral and Aesthetic," contains four chapters. Callan's essay is a sympathetic yet piercing analysis of the role reason plays in permitting a rationally justified faith and in supporting an enthusiastic worship of a deity. Shogan's discussion of gender and moral agency, Bailin's analysis of moral and aesthetic appreciation, and Richmond's arguments regarding art, politics, and aesthetic perspective all contribute to the general theme of this section-that is, moral and aesthetic values. Shogan shows that ethics of justice and care are not necessarily conflicting positions but, instead, may be complementary perspectives. Bailin delves into an analysis of appreciation and the implications of her analysis for moral and aesthetic education. Richmond's primary interest is in assisting art educators to chart a middle ground between "aesthetic universality and aesthetic relativism" (p. 106).

The fourth set of essays entitled simply "Literacy" examines the ways literacy may disempower or empower students. Textbooks are described by de Castell as officially authorized interpretations of ideas, events, and individuals that are in need of scrutiny by teachers and students. Her essay, which urges that textbooks be de-interpreted by students and teachers, is a suitable companion article to Portelli's later article in the final section "Dare We Expose the Hidden Curriculum?" Bodgan holds that when maturing students in a multicultural, liberal, democratic society are empowered to critique literature, tensions may arise which will be beyond resolution. In her discussion of pedagogies of detachment and engagement, nearly everyone concemed with real or imagined censorship can appreciate aspects of her analysis of the complexities of educating reflective students while attempting to avoid giving them a de facto veto power over curricular matters.

In the final grouping entitled "Autonomy: The Student and the Teacher," the subject of autonomy is approached from four perspectives. Callan's approach is a straightforward assault on positions that do not subscribe to the notion of allowing a full participation by students and teachers in the life of schools. Portelli views autonomy and related issues via the outcomes of enabling educators and students to understand the hidden curriculum. Ross castigates educational reform efforts that are rooted in a so-called science of pedagogical research that strips teachers of the responsibility to think for themselves about the presuppositions of researchers and the misapplications of their research by bureaucrats. Woodhouse is concerned primarily with discussing the 
deficiencies of Teacher Education in Ontario, a report that is described as antieducational, opposed to individual professionalism, and against collegiality and autonomy. In contrast to the report, Woodhouse recommends an individual professionalism that is rooted in disciplines, pedagogical knowledge, and critical thinking.

If the reader is looking for a collection of philosophical essays that introduces a number of educational issues to practitioners, this work may be suitable. For those who are looking for personal readings in contemporary analytic and normative philosophy of education on topics regarding religion, aesthetics, gender issues, censorship, student autonomy, and professionalism, the volume contains many worthwhile essays. The work should also be of interest to those who are interested in policy issues and ethical concerns. The volume may be slightly less serviceable for those who seek a collection of philosophical essays on educational topics that is designed for aspiring teachers who have little or no background in philosophy of education. Even in this regard, however, one might list some of the essays as required reading for students-for example, "Analytic Philosophy of Education: Development and Misconception," "Gender and Moral Agency," and "Teacher Empowerment: Unmasking Disciplinary Power."

Reviewed by Douglas J. Simpson, Texas Christian University

\section{Robin Barrow, Utilitarianism: A Contemporary Statement (Brookfield, VT: Edward Elgar Publishing, 1991).}

Twenty years ago, Bernard Williams expected to hear no more of utilitarianism which, to him and other anti-utilitarians, certainly looked moribund. However, his expectation and perception proved illusory. The subsequent publication of numerous significant articles and books on utilitarianism and the appearance in 1989 of a notable journal, Utilitas, demonstrate its continuing vigour as an ethical theory.

In Utilitarianism: A Contemporary Statement, Barrow notes that the potential of this theory has been vitiated by its having been misrepresented and misunderstood. Thus, the volume aims at presenting a coherent, viable theory and defending it against persistent objections. The result is a forceful version to welcome or contend with, but not ignore.

To pave the way for his version, Barrow strategically establishes (in Chapter 2) a defensible view of an ethical theory which attempts "to explicate what in ideal circumstances would constitute right conduct," rather than "provide unambiguously prescriptions for conduct in the imperfect world we inhabit"' (p. 12). He underlines the consequentialist character of utilitarianism which insists that the rightness of an act depends on whether it maximizes intrinsic good. Nevertheless, he rightly claims that his rule-utilitarian version "would accept that certain actions ought to be performed regardless of the consequences of performing them on particular occasions" (p. 19). Thus, he undercuts the alleged tension and (to him, unhelpful) distinction between teleological and deontological ethical theories.

In Chapters 3 and 4, Barrow lucidly outlines his reformulation of utilitarianism and its central premise of happiness. Claiming that happiness is 